\title{
Internal Control Practices and Financial Performance of County Governments in the Coastal Region of Kenya
}

\author{
Salma Omar Ahmed ${ }^{1}$, Peter Ng'anga ${ }^{2}$ \\ ${ }^{1}$ School of Business, Kenyatta University, Kenya \\ ${ }^{2}$ Lecturer Business Administration Department, School of Business, Kenyatta University, Kenya
}

ABSTRACT

Internal control practices have been established to influence financial performance of County Government, though County Government have been facing a myriad of challenges in terms of financial performance. The drive of this study was to establish internal control practices that influence county governments to streamline their operations and perform efficiently and effectively for the benefit of the general interest. Therefore the general objective of the study was to determine the internal control practices and financial performance of county governments in the coastal region of Kenya. Specifically, the study endeavored to establish the effect of audit function, risk management, financial reporting and cash management on financial performance of county governments in the coastal region. The study was based on the following theories: The Agency theory, Attribution theory and procedural justice theory. The researcher adopted a descriptive research design. The target population of the study were 30 employees drawn from 5 departments in the Ministry of Finance, Budget and planning in the county governments of the Coastal region. The study targeted 4 Counties in the coastal region of Kenya, that is Mombasa, Kilifi, Kwale and Taita and the respondents were 40 finance managers obtained from Finance Planning Ministry of the listed County governments. A census of 40 respondents was carried out. Primary data was collected using questionnaires. Data was analysed using descriptive statistics and inferential statistics. The study found a positive and significant effect between risk assessment, monitoring, control environment, information and communication on financial performance. The study concluded that the risk identification and mitigation play the most significant role in influencing financial performance of the County governments. Hence, risk identification can essentially be said to be the key starting point of any risk management program as the Counties cannot manage what is unknown. Monitoring the financial performance of the County creates more certainty and confidence in making both short and long term decisions. This in turn leads to a healthier business and faster growth rate. The control environment provides the basis for carrying out internal control across the organization. Effective adoption of information and communication systems is of vital importance in making sure that the County governments improves their financial performance. The study recommends that the management of the Counties should put in place cost-effective measures for timely risk identification and effective risk mitigation so as to ensure that their financial performance is not impacted negatively. The County governments should have appropriate tools for monitoring their financial performance so as to effectively monitor their goals, the progress they make and all the key performance metrics throughout their financial operations. The County governments should demonstrate a commitment to integrity and ethical values. Specific standards of conduct should be understood throughout all levels of the County, and processes should be in place to evaluate performance and quickly address deviations from expectations. The County governments should communicate successfully with their investors to form stronger relationships with them. Information and communication should be between the County and financial stakeholders about the County's economic events and their effects within and outside the 
financial statements.

Key words: Internal Control Practices, Risk Assessment, Monitoring, Control Environment, Information and Communication, Financial Performance, County Governments in the Coastal Region of Kenya

DOI: $10.35942 /$ ijcab.v3iV.59

\section{Cite this Article:}

Ahmed, S., \& Nganga, P. (2019). Internal Control Practices and Financial Performance of County Governments in the Coastal Region of Kenya. International Journal of Current Aspects, 3(V), 28-41. https://doi.org/10.35942/ijcab.v3iV.59

\section{Introduction}

Internal controls in accounting and auditing, refers to the assurance of the attainment of a firm's objectives in its efficiency and the compliance to laws, regulations and policies (Lumen, 2014). Internal controls are laws that safeguard the assets of an organization, provide dependable financial reporting, enhance compliance with regulations and laws and achieve efficiency in operations. These systems also adhere to the organizations communication processes, internally and externally, and include procedures for: - handling funds received and spend by the organization and reporting to county executive committee. They also conduct the organization's annual audit by auditor general and maintain inventory records of real and other properties. Brennan \& Soloman, (2008) and Treba (2003) explained that weaknesses in the systems (control over the payroll, over expenditure commitments and over procurement) results in the inability to guarantee that resources are taken to defined priorities and to guarantee that there is value for money will be attained in public spending. The absence the internal controls is the main cause of fraudulent financial reporting. Global corporate financial scandals of WorldCom and Enron in USA, Chuo Aoyama from Asia and Parmalat from Europe are examples of this (Treadway, 1987). In South Africa, cases of scandals include Randgold, JCI and Expedition companies. In Nigeria, Cadbury dismissed its leaders for inflating profits in 2006. These scandals emphasize a need to evaluate and formulate monitoring systems of to guide executives in decision making. These executives are lawfully and morally obligated to trustworthy and honest corporate financial reports periodically (Hayes, 2005).

Internal controls are procedures planned for the provision of logical security towards the achievement of the company's goal in an efficient, credible financial and administrative reporting, and finally conformance to the rules which safeguard the company's reputations, (Cunningham, 2004). According to Krishnan (2015) efficient internal controls creates an organization's confidence in its ability to perform or undertake a particular task and prevents errors and losses through monitoring and enhancing organizational and financial reporting processes as well as ensuring compliance with pertinent laws and regulations. Risk assessment is the process of identifying and analyzing management relevant risks to the preparation of financial statements that would be presented fairly in conformity with general accepted accounting principle, information and communication systems (Hassan Al-Tamimi \& Mohammed 2017). According to Abu Hussain and Al-Ajmi (2012) internal controls require that all pertinent information be identified, captured and communicated in a form and time frame that enable people to carry out their financial reporting responsibilities. Internal control enhances the provision of additional information to the principal (shareholder) about the behavior of the agent (management) reduces information asymmetry and lowers investor risk and low revenue. 
Therefore, it can be argued that strong internal control system help to prevent, minimize, transfer or eliminate risks, which may affect a profitable operation.

Monitoring of controls is the process of assessing the quality of the internal control structure over time. Since internal controls are processes, it is usually accepted that they need to be adequately monitored in order to assess the quality and the effectiveness of the system's performance over time (Shizhen, 2015). Gregersen and Lundgren (2016) indicate that effective financial monitoring systems are required in the quest to maximize the efficient use of resources, create the highest level of transparency and accountability in an organization's finances and to ensure long-term economic success. The control environment, as established by the organization's administration, sets the tone of an Institution and effects the control consciousness of its people. Management attitude should be committed to ethical business practices and to following the established control procedures (Anderson, Francis \& Stokes, 2013). This is the foundation for all other components of internal control, providing discipline and structure. DeAngelo (2015) show that control environment factors include: Integrity and ethical values; the commitment to competence; leadership philosophy and operating style; and the way management assigns authority and responsibility, and organizes and develops its people. The reliability of financial reporting is effective to internal control efficiency to ensure that transactions and bookkeeping are appropriate and properly authorized, valid, correctly recorded, complete, and on time. Moreover, it is very important that organizations have fairly summarized accounting information data disclosure (Jensen \& Meckling, 2016). According to Brennan and Solomon (2012) a quality reporting is affected by internal control mechanism. It is also a general belief that properly instituted systems of internal control improve the reporting process and also give rise to reliable reports which enhances the accountability function of management of an entity.

The financial performance is a term used in relation to the capacity of financial institution to generate sustainable profitability. For any financial institution to be successful in its operations, managers must weigh complex trade-offs between growths, return and risk, favouring the adoption of risk-adjusted metrics (Albertazzi \& Gambacorta, 2011). According to Agbada and Osuji (2013) the Return on Assets (ROA) is a key proxy measure frequently used in the literature of bank financial performance and reflects the management's ability and efficiency to utilize banks' financial and real investment resources to generate profits. The author further indicates that the ROA depends on the bank's policy decisions as well as on uncontrollable factors relating to the economy and government regulations. Financial performance refers to the degree to which financial objectives of an organization are accomplished. Financial performance will measure the results of a firm in monetary terms. Institutions will put in place best financial and non financial structures in place to have competitive advantage over their competitors. On the other hand, Amalendu and Sri (2011) show that poor financial performance of an institution will affect the attraction of institution to would be investors which may lead it to insolvency and eventual collapse. Financial performance is the measurement of how a business entity has utilized its resources to generate revenues. Financial performance is normally measured by the gearing ratios, profitability ratios and the liquidity ratios (Piper, 2010). Alfred, 2017) indicate that profitability ratios of any business entity portrays the picture of how well an entity has employed the resources efficiently, liquidity ratios deals with the capacity of business entities to accomplish the short term obligations and the gearing ratios indicates the extent of debt employment by the companies. 
Internal control systems including internal audits are intended primarily to enhance the reliability of financial performance, either directly or indirectly by increasing accountability among information providers in an organization (Jensen \& Meckling, 2016). As per Endaya and Hanefah (2016) internal control therefore has a much broader purpose in the organization level. Internal controls provide an independent appraisal of the quality of managerial performance in carrying out assigned responsibilities for better revenue generation. Effective internal control systems assist in the formulation and implementation of quality procurement procedures that helps to factor justification for requisition at proper lead-time, quantity and at lowest prices (Mihret, James \& Mula, 2010). This will boost profitability than blind ordering which result to loss and waste. Ahmad, Othman, Othman and Jusoff (2014) argue that it is very important for every section and department of an organization to have an effective internal control system which is involved in blocking the organization's income leakages and loop holes thereby supporting a sustained profitability, growth and other general corporate goals and objectives. Ouchi (2014) stated that internal control must be able to achieve the objective of bringing about cooperation among people with divergent objectives in an organisation. On the other hand, Financial Performance of an organization can be described in various form, such as; return on assets, return on sales, return on equity, return on investment, return on capital employed and sales growth. Sarens and Abdolmohammadi (2011) observe that it is also a measure of the excess value a company has provided to its shareholders over the total amount of their investment. Therefore, appropriate performance measures are those which enable organizations to direct their actions towards achieving their strategic objectives.

\section{Statement of the Problem}

Data from World Bank (2014) shows a decline in services in the economy especially the county government. Poor performance financially in county governments adversely affects the economic growth of Kenyan economy. Poor financial performance resulting from incompetent budgeting, and regulations in using finances are not adhered to and there is massive unaccounted of funds, incomplete records and book keeping management. This has led to risk of financial inadequacy, employee dissatisfaction and poor financial performance (Mikes \& Kaplan, 2014). Studies done relating to controls internally in relation to financial performance do not show directly the influence of governments' internal controls on financial performance. Some of the challenges experienced in the Counties include; financial reporting not being done on time, struggles with liquidity problems, fraud and misuse of County resources. Accountability for the financial resources is still wanting. Some of the decisions made did not yield expected results. Njeri (2014) study examined the effect of internal controls on the financial performance of manufacturing firms in Kenya and found that there is a positive relationship between internal control and financial performance of manufacturing firms in Kenya. However, the study used simple random sampling which is subject to sample biasness. Njiru (2016) did a study on the effect of internal controls on financial performance of public water companies in Kenya and established a positive significance relationship between internal controls and financial performance. However, the study used convenience sampling method which is a non probabilistic sampling methods. Muhunyo and Jagongo (2018) study investigated the effect of internal control systems on financial performance of public institutions and revealed that the control environment, risk assessment, control activities and information and communication as indicators of internal control systems have a significant influence on the financial performance. However, the study used secondary data which may not be specific to the needs of a researcher. Consequently, this study sought to close the knowledge gap that exists by determining the effect 
of internal control practices and the financial performance in the county government.

\section{Objectives of the Study}

The general objective of this study was to investigate the effects of internal control practices and financial performance of County Governments in the Coastal Region of Kenya.

Specific objectives were:

i. To determine the effect of risk assessment on financial performance of County Governments in the Coastal Region of Kenya.

ii. To establish the effect of monitoring on financial performance of County Governments in the Coastal Region of Kenya.

iii. To investigate the effect of control environment on financial performance of County Governments in the Coastal Region of Kenya.

iv. To examine the effect of information and communication on financial performance of County Governments in the Coastal Region of Kenya.

\section{Theoretical Framework}

\subsection{Agency Theory}

Agency theory was developed in 1976 by Jensen and Meckling. This theory is an agency relationship as a contract under which one or more persons (the principal(s)) engage another person (the agent) to perform some service on their behalf which involves delegating some decision-making authority to the agent. Agency theory analyses the relationship between two parties: investors and managers. The agent (manager) undertakes to perform certain duties for the principal (investors) and the principal undertakes to reward the agent. As such, the theory describes firms as necessary structures to maintain contracts, and through firms, it is possible to exercise control which minimizes opportunistic behavior of agents (Mwangi, 2012). According to the theory, in order to harmonize the interests of the agent and the principal, a comprehensive contract is written to address the interest of both the agent and the principal. The agent-principal relationship is strengthened more by the principal employing an expert and systems (auditors and control systems) to monitor the agent. This theory is applicable to this study simply because internal control is one of many mechanisms used in business to address the agency problem by reducing agency costs that affects the overall performance of the relationship as well as the benefits of the principal (Payne, 2003; Abdel-Khalik, 1993). Internal control enhances the provision of additional information to the principal (shareholder) about the behavior of the agent (management) reduces information asymmetry and lowers investor risk and low revenue.

\subsection{Attribution Theory}

Attribution theory is a social psychology theory that explores how people interpret events and behaviors and how they ascribe causes to the events and behaviors. Bonner et al. (1998) found that auditors are more likely to be sued when they fail to detect common misappropriations that would result to decreased revenues, and the evaluators believe that the fraud could have been detected by other auditors. The auditor's accountability for detecting fraud is extended by Reffett's (2007) study which predicted that auditors are more likely to be held accountable by evaluators when the auditors fail to detect fraud after they had identified the fraud occurrence as a fraud risk. The result of Reffett's study shows an increase in auditors ${ }^{\text {ee }}$ liability when an audit 
fails, after the auditors had identified the perpetrated fraud as a fraud risk and performed procedures to investigate the identified fraud risk. The findings support Reffett's prediction. According to Bonner et al. (1998), evaluators can use the audit processes as a basis to determine negligence if auditors fail to detect internal control related fraud that may occur. This theory is relevant to the study in that it suggests that when fraud occurs, identified parties should be held accountable and auditors are most likely to be held accountable if evaluators determine substandard audit services were provided.

\subsection{Procedural Justice Theory}

Procedural justice deals with fairness in resolving disputes and allocating resources. Procedural justice theory is a social psychology theory concerned with decision making process and the effect of the process on social relationship. The theory deals with what constitutes fair decision procedures, and is the basis for the practice of decision-makers to use and apply laws or criteria that they believe are fair, just, and necessary in the decision making process (Patterson \& Smith, 2007). External attribution occurs, if an auditor perceives the procedures as being unfair, and their litigation as negative (Carter, 1991). Procedural justice theory purports that there is there is need for fairness and communication in the workplace which is consistent with moral and ethical values. This establishes internal control systems and financial performance (Steven 2003).

\section{Empirical Literature}

This section covers the review of previous studies touching about the specific objectives of the study which include risk assessment, monitoring, control environment and information and technology on financial performance. These are discussed as follows;

\subsection{Risk Assessment and Financial Performance}

Olalere and Wan (2016) carried out a study on the relationship between risk assessment and the financial performance of Commercial Banks in Nigeria: A literature review revisited. It establish that poor risk management reduced profitability and it results to low profit margin of the company or be more extraneous in highly competitive market. Hence, the paper concludes that for profitability to be attained, the bank must adhere its financial operations with different regulations and guidelines. Mariam and Onyiego (2018) study explored the effect of risk assessment on financial performance of Commercial Banks in Kenya: A Case Study of Commercial Banks in Mombasa County. The study concluded that operational risk management was the key variable in determining performance of commercial banks in Kenya. The study also concluded that credit risk management significantly affects the financial performance of commercial banks because of failure of counterparties to fulfil their obligations. The findings of the study also established that liquidity risk management significantly influences financial performance of commercial banks. Mardiana and Dianata (2018) study investigated the effect of risk assessment on financial performance with good corporate governance as a moderation variable. he data used is obtained from the Financial Statements of Sharia Banking Companies Listed on Indonesia Stock Exchange in the period 2011 to 2016. After passing through the stage of purposive sampling, the worthy of used sample is 5 Companies. The results showed that the variable of Capital Adequacy Ratio (CAR), and Non Performing Loan (NPL) had negative and insignificant effect on Return on Asset (ROA), and operating efficiency had negative and significant effect on Return on Assets (ROA). 


\subsection{Monitoring and Financial Performance}

A study carried out by Emilly, Muganda and Singoro (2018) examined the effects of monitoring on financial performance of Public Sugar Firms in Kenya. The study adopted descriptive survey research design. Both descriptive and inferential statistics were used to analyze the data. The study revealed that the two Budget Participation and Budget Communication had significantly strong positive relationship with the Financial Performance of the Public Sugar Firms in Kenya. The study revealed and concluded that Budget Participation and Budget Communication had significant influence on the financial performance of Public Sugar Firms in Kenya. Kisanyanya (2018) study investigated the effects of monitoring and financial performance of Public Institutions of Higher Learning in Vihiga County, Kenya. Primary data was collected from sample population using semi-structured questionnaires. Descriptive and multiple regression analysis were used to analyze data. Financial monitoring was found to have a positive and significant effect on the financial performance of the institutions under study. The study found that the institutions had adequate and effective control activities which included regular internal audit reports, adequate segregation of duties in the finance and accounts departments and physical controls to prevent excess allocated funds. Ng'wasa (2017) study examined the link between monitoring and financial performance in financial institutions. Purposive sampling technique was used to select 88 sample size of this study. Data collected through documentary review and questionnaires were analyzed using descriptive statistics and regression methods. Based on the data analyzed, findings showed that there was no any significant relationship between budget monitoring and financial performance. However, these results found the existing significant relationship between budgetary planning and financial performance.

\subsection{Control Environment and Financial Performance}

Kinyua, Gakure, Gekara and Orwa (2015) study investigated the effect of internal control environment on the financial performance of companies quoted in the Nairobi Securities Exchange. Primary data was collected using structured questionnaires while the Secondary data was extracted from audited annual reports, publications and document analysis. Data analysis used both descriptive and inferential statistics. The results and findings concluded that there was significant association between internal control environment and financial performance recommends that internal control environment should be enhanced to further improve the financial performance of companies quoted in Nairobi Securities Exchange. Kamau (2014) investigated the effect of internal controls on the financial performance of manufacturing firms in Kenya. The findings revealed that most manufacturing firms had a control environment as one of the functionality of internal controls of the organization that greatly impacts on the financial performance of the firms. The results also revealed that the staffs were trained to implement the accounting and financial management systems, the security system identified and safeguarded organizational assets. The statistical result from the regression analysis shows that there is a positive relationship between internal control and financial performance of manufacturing firms in Kenya. D'Aquila (2014) study concentrated on whether the control environment is related to financial reporting decisions. The results were based on a survey mailed to 400 employees who prepare financial reports. The findings indicated that there is some reason for concern about fraudulent financial reporting. In addition, a tone at the top in an organization that fosters ethical decisions is of overriding importance to reliable financial reporting. Codes of conduct and pressure for short-term performance, alone, had no significant effect on financial reporting decisions. The findings emphasize the importance of learning about an organization's tone at the 
top during an audit.

\subsection{Information and Communication on Financial Performance}

Kanuna (2013) study examined the effects of information communication technology on financial performance of courier service providers in Kenya: A Case Study of Document Handling Limited. This study adopted a survey research method to show the relationship between information's communications Technology and performance practices. The secondary data was collected from the financial statements of Document Handling Limited and books to collect information on annual earnings of the Company. The findings of the study revealed a strong positive correlation between the predictor's variables and independent variables. Chege (2016) study investigated the effects of information communication technology adoption on financial performance of financial institutions in Kenya. This study adopted a descriptive research design and the population of study consisted of all the 258 financial institutions in Kenya as at 2015. Simple random sampling technique was applied to select a sample size of 78 financial institutions. The study applied primary data using questionnaires and secondary data collected from the respective institution' financial statements and summaries at the Central bank of Kenya. Adoption of ATM technology had improved cost efficiency in the institutions, improved fraud risk management in the bank an improved new customer enrolment in the institutions. Mwangi (2012) study evaluated the Impact of information communication technology development on financial performance of Commercial Banks in Kenya. The research data was collected through use of questionnaires. The respondents were employees of commercial banks in Kenya. Data was collected from all the 44 commercial banks in Kenya. From the analysis of data collected, it can be seen that investment on ICT systems and infrastructure has been a key element in productivity and growth in the banking industry. This study indicates that ICT enables banks to offer a broad variety of services to customers.

\section{Research Methodology}

The study used descriptive survey research design. The purpose of descriptive research was description of the state of affairs as it exists at present. The study targeted 4 Counties in the coastal region of Kenya, that is Mombasa, Kilifi, Kwale and Taita and the respondents were 40 finance managers obtained from Finance Planning Ministry of the listed County governments. Research instrument to be used was questionnaire which was considered the most suitable instrument for descriptive research design. The questionnaires were used since they required less time, were less expensive, permitted collection of data derived from a wide population and respondents' anonymity ensured that they gave honest answers. The administrators of the selected Counties were contacted to permit the researcher to carry out the study. The researcher personally administered the questionnaires to the sampled respondents. The respondents were given two weeks for filling in the questionnaires. The researcher made a visit to the respondents to remind them on the importance of filling the questionnaires so as to ensure high response rate. Primary data from the field was edited to eliminate errors that could have been made by the respondents. Coding was done to translate question responses into specific categories so as to organize and reduce research data into manageable summaries. Quantitative data was analyzed using descriptive statistics such as mean and standard deviation and presented in form of tables, pie-charts and bar-graphs where applicable with the aid of Statistical Package for Social Sciences (SPSS) version 20.0. Inferential statistics such as multiple regressions was used to determine the relationship between variables. 


\section{Research Findings}

Correlation analysis was performed to show the relationship between the study variables. The results are presented in Table 1.

Table 1: Correlation Analysis

\begin{tabular}{|ll|c|c|c|c|}
\hline & & $\begin{array}{c}\text { Risk } \\
\text { assessment }\end{array}$ & $\begin{array}{c}\text { Monitorin } \\
\mathrm{g}\end{array}$ & $\begin{array}{c}\text { Information } \\
\text { and } \\
\text { Control } \\
\text { environment }\end{array}$ & $\begin{array}{c}\text { comicati } \\
\text { on }\end{array}$ \\
\hline Risk assessment & Pearson Correlation & 1 & .790 & .107 & .218 \\
& Sig. (2-tailed) & & .001 & .524 & .189 \\
& $\mathrm{~N}$ & 38 & 38 & 38 & 38 \\
\hline Monitoring & Pearson Correlation & .790 & 1 & $.681^{* * *}$ & .307 \\
& Sig. (2-tailed) & .001 & & .000 & .061 \\
& $\mathrm{~N}$ & 38 & 38 & 38 & 38 \\
\hline Control environment Pearson Correlation & .107 & $.681^{* *}$ & 1 & .040 \\
& Sig. (2-tailed) & .524 & .000 & & .812 \\
& $\mathrm{~N}$ & 38 & 38 & 38 & 38 \\
\hline Information & and Pearson Correlation & .218 & .307 & .040 & 1 \\
communication & Sig. (2-tailed) & .189 & .061 & .812 & \\
\multicolumn{1}{|l|}{$\mathrm{N}$} & 38 & 38 & 38 & 38 \\
\hline
\end{tabular}

Source: Survey Data (2019)

The Pearson's $r$ for the correlation between risk assessment and monitoring variables is 0.790 which is close to 1 with a significant value of 0.00 which is less than 0.05 . This shows a strong relationship meaning that changes in one variable are strongly correlated with changes in the second variable. Mariam and Onyiego (2018) study established that liquidity risk management significantly influences financial performance of commercial banks. Monitoring is strongly related to control environment $(\mathrm{r}=0.681, \mathrm{p}<0.05)$ which means that increase in monitoring leads to increase in control environment and vice versa. A study carried out by Kisanyanya (2018) study investigated the effects of monitoring and financial performance of Public Institutions of Higher Learning in Vihiga County, Kenya found that financial monitoring was found to have a positive and significant effect on the financial performance of the institutions under study.

Table 2: Regression Analysis

\begin{tabular}{|c|c|c|c|c|c|c|c|c|c|}
\hline \multirow[b]{2}{*}{$\begin{array}{l}\text { Mod } \\
\text { el }\end{array}$} & \multirow[b]{2}{*}{$\mathrm{R}$} & \multirow[b]{2}{*}{$\begin{array}{c}\mathrm{R} \\
\text { Square }\end{array}$} & \multirow[b]{2}{*}{$\begin{array}{c}\text { Adjusted R } \\
\text { Square }\end{array}$} & \multirow{2}{*}{$\begin{array}{l}\text { Std. Error } \\
\text { of the } \\
\text { Estimate }\end{array}$} & \multicolumn{5}{|c|}{ Change Statistics } \\
\hline & & & & & $\begin{array}{c}\text { R Square } \\
\text { Change }\end{array}$ & $\begin{array}{c}\mathrm{F} \\
\text { Change }\end{array}$ & df1 & df2 & $\begin{array}{l}\text { Sig. F } \\
\text { Change }\end{array}$ \\
\hline 1 & $.765^{\mathrm{a}}$ & .585 & .535 & .353 & .585 & 11.633 & 4 & 33 & .000 \\
\hline
\end{tabular}

Source: Survey Data (2019) 
The four independent variables that were studied, explain $53.5 \%$ of the financial performance of County governments in Coastal region as represented by the adjusted $\mathrm{R}$ square. This therefore means that other factors not studied in this research contribute $46.5 \%$ of the financial performance.

Table 3: Analysis of Variance

\begin{tabular}{|ll|r|r|r|r|r|}
\hline Model & Sum of Squares & df & Mean Square & F & Sig. \\
\hline 1 & Regression & 5.789 & 4 & 1.447 & 11.633 & $.000^{\mathrm{a}}$ \\
& Residual & 4.105 & 33 & .124 & & \\
& Total & 9.895 & 37 & & & \\
\hline
\end{tabular}

Source: Survey Data (2019)

The significance value is $0.000^{\mathrm{a}}$ which is less that 0.05 thus the model is statistically significance in predicting how the independent variables studied influenced the financial performance of County governments in Coastal region. The F calculated at 5\% level of significance was 11.633. Since F calculated is greater than the F critical ( $\mathrm{p}$ value $=1.447$ ), this shows that the overall model was significant.

Table 4: Coefficients

\begin{tabular}{|c|c|c|c|c|c|c|}
\hline \multirow{2}{*}{\multicolumn{2}{|c|}{ Model }} & \multicolumn{2}{|c|}{$\begin{array}{l}\text { Unstandardized } \\
\text { Coefficients }\end{array}$} & \multirow{2}{*}{$\begin{array}{l}\text { Standardized } \\
\text { Coefficients } \\
\text { Beta }\end{array}$} & \multirow[b]{2}{*}{$\mathrm{t}$} & \multirow[b]{2}{*}{ Sig. } \\
\hline & & B & Std. Error & & & \\
\hline 1 & (Constant) & .438 & 1.016 & & 1.121 & .000 \\
\hline & Risk assessment & .523 & .056 & 1.047 & 1.407 & .001 \\
\hline & Monitoring & 859 & .073 & 5.448 & 2.695 & .002 \\
\hline & Control environment & .797 & .138 & 2.980 & 6.212 & .000 \\
\hline & $\begin{array}{l}\text { Information and } \\
\text { communication }\end{array}$ & .697 & .162 & 3.073 & 1.597 & .003 \\
\hline
\end{tabular}

Source: Survey Data (2019)

From the above regression model, holding risk assessment, monitoring, control environment and information and communication constant, the financial performance of County governments in coastal region would be 0.438 . The established regression equation by the study was $\mathrm{Y}=0.438+$ $0.523 \mathrm{X}_{1}+0.859 \mathrm{X}_{2}+0.797 \mathrm{X}_{3}+0.697 \mathrm{X}_{4}$ Where $\mathrm{Y}=$ Financial Performance; $\mathrm{X}_{1}=$ Risk assessment; $\mathrm{X}_{2}=$ Monitoring; $\mathrm{X}_{3}=$ Control environment; $\mathrm{X}_{4}=$ Information and communication. As shown in table 3risk assessment, monitoring, control environment and information and communication had a positive and significant effect on the financial performance of County governments in coastal region as indicated by t-values. The relationships $(\mathrm{p}<0.05)$ are all significant with risk assessment $(\mathrm{t}=1.407, \mathrm{p}<0.05)$, monitoring $(\mathrm{t}=2.695, \mathrm{p}<0.05)$, control environment $(\mathrm{t}=6.212, \mathrm{p}<0.05)$ and information and communication $(\mathrm{t}=1.597, \mathrm{p}<0.05)$. Monitoring was found to have a greater effect on financial performance at $85.9 \%$ ) followed by control environment (79.7\%), information and communication (69.7\%) and risk assessment (52.3\%). According to Abu Hussain and Al-Ajmi (2012) internal controls require that all pertinent information be identified, captured and communicated in a form and time frame that enable people to carry out their financial reporting responsibilities. Gregersen and Lundgren 
(2016) indicate that effective financial monitoring systems are required in the quest to maximize the efficient use of resources, create the highest level of transparency and accountability in an organization's finances and to ensure long-term economic success. Management attitude should be committed to ethical business practices and to following the established control procedures (Anderson, Francis \& Stokes, 2013). According to Brennan and Solomon (2012) a quality reporting is affected by internal control mechanism.

\section{Conclusions}

The study concludes that risk identification and mitigation play the most significant role in influencing financial performance of the County governments. Hence, risk identification can essentially be said to be the key starting point of any risk management program as the Counties cannot manage what is unknown. On the other hand, once identified, risks must be mitigated so that the impact on the firm is reduced. Monitoring the financial performance of the County creates more certainty and confidence in making both short and long term decisions. This in turn leads to a healthier business and faster growth rate. By capturing data and monitoring their performance, the County governments have a consistent and effective platform for making decisions. The control environment provides the basis for carrying out internal control across the organization. Comprises the tone at the top, communication about ethical behavior and internal control with all levels of staff, and the overall integrity and values of the organization. These components provide the overall basis for a successful system of internal control. Effective adoption of information and communication systems is of vital importance in making sure that the County governments improves their financial performance. It also improves the standards of service delivery. Effective employee communication is a leading indicator of financial performance and a driver of employee engagement.

\section{Recommendations for Policy and Practice}

The study recommends that the management of the Counties should put in place cost-effective measures for timely risk identification and effective risk mitigation so as to ensure that their financial performance is not impacted negatively. They should continuously assess their risk management practices to see if they are still practical in the face of a continuously changing operating environment. The County governments should have appropriate tools for monitoring their financial performance so as to effectively monitor their goals, the progress they make and all the key performance metrics throughout their financial operations. They should integrate their accounting and other software they use to run their business, automate data flow and provide real time information. The County governments should demonstrate a commitment to integrity and ethical values. Specific standards of conduct should be understood throughout all levels of the County, and processes should be in place to evaluate performance and quickly address deviations from expectations. The County should hold individual employees accountable for their internal control responsibilities in the pursuit of objectives. The County governments should communicate successfully with their investors to form stronger relationships with them. Information and communication should be between the County and financial stakeholders about the County's economic events and their effects within and outside the financial statements. The County governments should consider that every employee can share their experiences working for the County and where every customer can provide feedback for other customers. 


\section{REFERENCES}

Abu Hussain, H., \& Al-Ajmi, J. (2012). Risk management practices of conventional and Islamic banks in Bahrain. The Journal of Risk Finance, 13(3), 215-239.

Agbada, A. O., \& Osuji, C. C. (2013). The efficacy of liquidity management and banking performance in Nigeria. International review of management and business research, 2(1), 223-233

Ahmad, N., Othman, R., Othman, R., \& Jusoff, K. (2014). The effectiveness of internal audit in Malaysian public sector. Journal of Modern Accounting and Auditing, 5(9), 53 - 61

Albertazzi, U., \& Gambacorta, L. (2011). Bank profitability and the business cycle. Journal of Financial Stability, 5(4), 393-409

Alfred, D. D. (2017). Corporate Finance (2 ${ }^{\text {nd }}$ ed) New York: High Rise Publishers

Amalendu, B. I. \& Sri, B. B. (2011). Importance of Liquidity Management on Profitability. Asian Journal of Business Management, 3(2), 108 - 117

Anderson, D., Francis, J. R., \& Stokes, D. J. (2013). Auditing, directorships and the demand for monitoring. Journal of accounting and public policy, 12(4), 353 - 375.

Brennan, N. M., \& Solomon, J. (2012). Corporate governance, accountability and mechanisms of accountability: an overview. Accounting, Auditing \& Accountability Journal, 21(7), 885 906.

Chege, E. S. (2016). Effects of information communication technology adoption on financial performance of financial institutions in Kenya (Master's Project, University of Nairobi)

D’Aquila, J. M. (2014). Is the control environment related to financial reporting decisions?. Managerial Auditing Journal, 13(8), 472 - 478.

DeAngelo, L. E. (2015). Auditor size and audit quality. Journal of accounting and economics, 3(3), 183 - 199.

Emilly, M. S., Muganda, M. M., \& Singoro, B. (2018). Budget Monitoring and Financial Performance of Public Sugar Firms in Kenya. International Journals of Academics \& Research, 1(1), $287-291$

Endaya, K. A., \& Hanefah, M. M. (2016). Internal auditor characteristics, internal audit effectiveness, and moderating effect of senior management. Journal of Economic and Administrative Sciences, 32(2), 160-176.

Gregersen, H. \& Lundgren, A. (2016). Liking monitoring and assessment to sustainable development, University of Mennesota College of Natural Resources

Guest, G. (2013). Describing mixed methods research: An alternative to typologies. Journal of Mixed Methods Research, 7(2), 141-151

Hassan Al-Tamimi, H. A., \& Mohammed Al-Mazrooei, F. (2017). Banks' risk management: a comparison study of UAE national and foreign banks. The Journal of Risk Finance, 8(4), $394-409$.

Jensen, M. C., \& Meckling, W. H. (2016). Theory of the firm: Managerial behavior, agency costs and ownership structure. Journal of financial economics, 3(4), 305 - 360. 
Kanuna, L. M. (2013). The Effects of Information Communication Technology on Financial Performance of Courier Service Providers in Kenya: A Case Study Of Document Handling Limited (Doctoral dissertation, University of Nairobi).

Kinyua, J. K., Gakure, R., Gekara, M., \& Orwa, G. (2015). Effect of internal control environment on the financial performance of companies quoted in the Nairobi Securities Exchange. International Journal of Innovative Finance and Economics Research, 3(4), $29-48$.

Kisanyanya, G. A. (2018). Internal Control Systems and Financial Performance of Public Institutions of Higher Learning in Vihiga County, Kenya (Doctoral dissertation, Kenyatta University).

Kothari, C. (2004). Research Methodology, Methods and Techniques. New Age International Ltd, New Delhi

Krishnan, J. (2015). Audit committee quality and internal control: An empirical analysis. The accounting review, 80(2), 649 - 675.

Mardiana, M., \& Dianata, A. W. M. (2018). The effect of risk management on financial performance with good corporate governance as a moderation variable. Management and Economics Journal (MEC-J), 2(1), 257 - 268.

Mariam, M. A., \& Onyiego, G. (2018). Effect of Risk Management on Financial Performance of Commercial Banks in Kenya: A Case Study of Commercial Banks in Mombasa County. Strategic Journal of Business \& Change Management, 5(4), 12 - 23

Mihret, D. G., James, K., \& Mula, J. M. (2010). Antecedents and organisational performance implications of internal audit effectiveness: some propositions and research agenda. Pacific Accounting Review, 22(3), 224-252.

Muhunyo, B. M. \& Jagongo, A. O. (2018). Effect of internal control systems on financial performance of public institutions of higher learning in Nairobi City County, Kenya. International Academic Journal of Human Resource and Business Administration, 3(2), $273-287$

Mwangi, B. M. (2012). The Impact of Information Communication Technology Development on Financial Performance of Commercial Banks in Kenya (Master's project, University of Nairobi)

Ng'wasa, N. J. (2017). The link between monitoring and financial performance in financial institutions. A Case Of National Microfinance Bank (Nmb) Zonal Office (Central Zone) Dodoma (Doctoral dissertation, Mzumbe University).

Njeri, C. K. (2014). Effect of internal controls on the financial performance of manufacturing firms in Kenya. Unpublished Thesis.

Njiru, D. (2016). The effect of internal controls on financial performance of public water companies in Kenya (Doctoral dissertation, KCA University).

Olalere, O. E., \& Wan, A. B. O. (2016). Risk management and the financial performance of Commercial Banks in Nigeria: A literature review revisited. IOSR Journal of Economics and Finance, 7(2). $110-119$ 
Orodho J. A. (2005). Techniques of Writing Research Proposals and Reports in Education and Social Sciences. Nairobi: Masola Publishers

Ouchi, W. G. (2014). A conceptual framework for the design of organizational control mechanisms. Management science, 25(9), 833 - 848.

Piper, J. A. (2010). Determinants of Financial Control Systems for Multiple Retailers - Some Case Study Evidence. Managerial Finance, 6(1), 52 - 62.

Sarens, G., \& Abdolmohammadi, M. J. (2011). Monitoring effects of the internal audit function: agency theory versus other explanatory variables. International Journal of Auditing, 15(1), 1 - 20.

Shizhen, L. (2015). Modern financial management system. The Journal of Humanitarian Assistance, 4(2), 43 - 46.

This is an open-access article published and distributed under the terms and conditions of the $(\mathrm{cc}) \mathrm{EY}$ Creative Commons Attribution 4.0 International License of United States unless otherwise stated. Access, citation and distribution of this article is allowed with full recognition of the authors and the source.

Authors seeking to publish with an International Peer Reviewed Journal should consider www.ijcab.org by writing to the Editor at editor@ijcab.org. The articles must be quality and meet originality test. 